\title{
Measuring the effectiveness of work-life balance strategies in the manufacturing sector
}

\begin{tabular}{|c|c|}
\hline $\begin{array}{l}\text { Authors: } \\
\text { Idris O. Ganiy } \\
\text { Evelyn Derera } \\
\text { Sulaiman O. A } \\
\text { Ziska Fields }{ }^{4} \text { (D }\end{array}$ & $\begin{array}{l}1^{1} \text { (D) } \\
\text { id } \\
i u^{3} \text { (D) }\end{array}$ \\
\hline $\begin{array}{l}\text { Affiliations: } \\
{ }^{1} \text { Department } \\
\text { Resource Man } \\
\text { Faculty of Law } \\
\text { Management, } \\
\text { KwaZulu-Nata } \\
\text { South Africa }\end{array}$ & $\begin{array}{l}\text { f Human } \\
\text { agement, } \\
\text { and } \\
\text { University of } \\
\text {, Durban, }\end{array}$ \\
\hline $\begin{array}{l}{ }^{2} \text { Department } \\
\text { and Entrepren } \\
\text { Faculty of Law } \\
\text { Management, } \\
\text { KwaZulu-Nata } \\
\text { South Africa }\end{array}$ & $\begin{array}{l}\text { f Management } \\
\text { eurship, } \\
\text { and } \\
\text { University of } \\
\text { Durban, }\end{array}$ \\
\hline $\begin{array}{l}{ }^{3} \text { Harold Pupke } \\
\text { School of Busi } \\
\text { University of S } \\
\text { Technology, W } \\
\text { Namibia }\end{array}$ & $\begin{array}{l}\text { witz Graduate } \\
\text { ness, Namibia } \\
\text { cience and } \\
\text { indhoek, }\end{array}$ \\
\hline $\begin{array}{l}{ }^{4} \text { Department } \\
\text { Management, } \\
\text { Business and } \\
\text { University of J } \\
\text { Johannesburg }\end{array}$ & $\begin{array}{l}\text { f Business } \\
\text { College of } \\
\text { conomics, } \\
\text { ohannesburg, } \\
\text { South Africa }\end{array}$ \\
\hline $\begin{array}{l}\text { Research Proje } \\
\text { Project Numb } \\
\text { HSS/0104/016 }\end{array}$ & $\begin{array}{l}\text { ct Registration: } \\
\text { er: } \\
\text { D }\end{array}$ \\
\hline $\begin{array}{l}\text { Correspondin } \\
\text { Idris Ganiyu, } \\
\text { idris_olayiwol } \\
\text { com }\end{array}$ & author: \\
\hline $\begin{array}{l}\text { Dates: } \\
\text { Received: } 17 \\
\text { Accepted: } 27 \\
\text { Published: } 08\end{array}$ & $\begin{array}{l}\text { May } 2019 \\
\text { eb. } 2020 \\
\text { June } 2020\end{array}$ \\
\hline Read online: & \\
\hline 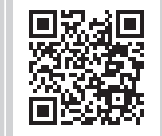 & $\begin{array}{l}\text { Scan this QR } \\
\text { code with your } \\
\text { smart phone or } \\
\text { mobile device } \\
\text { to read online. }\end{array}$ \\
\hline
\end{tabular}

Orientation: The development of an appropriate framework to measure the effectiveness of work-life balance strategies (WLBS) among manufacturing firms in Nigeria is still a major challenge.

Research purpose: The main purpose of this article is to measure the effectiveness of WLBS in the manufacturing sector, drawing insights gathered from two selected manufacturing firms in Lagos metropolis, Nigeria.

Motivation for the study: Despite the global explosion of research on work-life balance, there is a dearth of studies measuring the effectiveness of WLBS adopted by manufacturing firms in Nigeria.

Research approach/design and method: A structured questionnaire was adopted to gather data among 312 employees of the two selected manufacturing firms in Lagos Metropolis, Nigeria. Structural Equation Modelling was valuable in establishing the mediating influences of WLBS and work-family satisfaction on the interplay between work-family stressors and the selected manufacturing firms' performance.

Main findings: The study findings revealed that WLBS and work-family satisfaction mediate the interplay between work-family stressors and the selected manufacturing firms' performance.

Practical/managerial implications: To enhance continuous performance, human resource managers of the manufacturing firms should ensure the improved implementation and adoption of relevant WLBS that could help the employees cushion the effect of work and family stressors thereby achieving satisfaction with work and family life.

Contribution/value-add: This study develops and validates a framework to measure the effectiveness of WLBS in selected manufacturing firms, Lagos Metropolis. The developed framework could serve as a template which could be replicated in other sectors of the Nigeria's economy.

Keywords: effectiveness of work-life; work-life balance strategies; WLBS; manufacturing sector; Nigeria.

\section{Introduction and background}

The work-life debate is a common discourse in developed countries such that appropriate worklife balance strategies (WLBS) are provided to ensure employees achieve the right mix between work and family domains (Brochard \& Letablier, 2017). Previous studies have shown that despite robust frameworks on WLBS in developed countries, gaps have continued to emerge between the ideal and the actual work-life balance issues because of the changing structure of work (Akanji, Mordi, \& Ojo, 2015; Rodó-de-Zárate et al., 2016). A recent study conducted by Agba, Wilson and Innah (2015) has revealed that employees in Nigeria are finding it difficult to balance between work and family roles, which is affecting productivity in both domains. Many firms have put in place various WLBS such as parental leave, employees' health and wellness programme, dependent care, personal development and flexible work arrangement to overcome this challenge (Abe, Abe, Fields, \& Idris, 2018). However, the effectiveness of these WLBS in helping employees to cope with work and family stressors is still in doubt (Agba et al., 2015; De Cieri, Holmes, Abbott, \& Pettit, 2005; Zheng et al., 2016).

How to cite this article: Ganiyu, I.O., Derera, E., Atiku, S.O., \& Fields, Z. (2020). Measuring the effectiveness of work-life balance strategies in the manufacturing sector. SA Journal of Human Resource Management/SA Tydskrif vir Menslikehulpbronbestuur, 18(0), a1216. https:// doi.org/10.4102/sajhrm.v18i0.1216

Copyright: @ 2020. The Authors. Licensee: AOSIS. This work is licensed under the Creative Commons Attribution License. 
Researchers have recognised WLBS as viable human resource (HR) tool which could be adopted in the promotion of organisational efforts aimed at attracting, retaining and motivating the employees (Wei, Yili, \& Tian, 2013). Much of the research efforts have focused on high commitment HR systems which are aimed at helping the workforce to develop prospects in decision-making process and rewards for performance (Guest, 2017). The issue of work-life balance has been viewed as strategic element in the performance of HR function (Hirschi, Shockley, \& Zacher, 2019; Wei et al., 2013). Evidence has revealed that the availability of WLBS in an organisation do not suggest such strategies are properly implemented and utilised (Hirschi et al., 2019). Fleetwood (2007) points out that current HR practices with respect to WLBS are characterised by practices that are not favourable to employees. The devolution of HR function to line managers implies that a disparity and inconsistency may arise in the HR strategy formulated at the higher hierarchy of HR and the actual implementation by line managers (McCarthy, Darcy, \& Grady, 2010).

\section{Overview of Nigeria's manufacturing sector}

Nigeria is the most populous country in Africa with a population of over 170 million (Ogunnubi, 2017). Located in West Africa, Nigeria has emerged as the largest economy in Africa with a gross domestic product (GDP) of over US\$500 billion (Odubajo \& Akinboye, 2017; Ogunnubi, 2017). The economic influence of Nigeria in the West Africa sub-region is traced by the presence of its commercial banks propelling commercial activities in 16 countries of the sub-region, with Lagos stock exchange as the only financial trading stock exchange (Olugbenga \& Grace, 2016). Nature has endowed Nigeria with rich human and natural resources. The discovery of oil in commercial quantity has resulted in the neglect of other sectors of the economy which could enhance the country's quest for industrialisation (Ehie \& Muogboh, 2016; Olugbenga \& Grace, 2016). The oil and gas sector accounts for over $85 \%$ of Nigeria's GDP, whilst industrial and manufacturing sector contribute $6 \%$ and $4 \%$ GDP respectively (Chete, Adeoti, Adeyinka, \& Ogundele, 2016).

Manufacturing activities are traced to the 19th century Industrial Revolution in Europe (Mokyr, 2018). This period marked the beginning of a new order of economic growth and development in the Western world. The manufacturing sector was viewed as the engine of industrialisation around the world (Raphael \& Gabriel, 2015). Governments in African nations considered manufacturing sector as a springboard for modernisation with a knack of creating employment (Mokyr, 2018). An empirical study revealed that between 1992 and 2012, one-third of the global manufacturing output was produced in developing countries of Asia and Africa, with China leading the pack (Newman et al., 2016). Corroborating this study, Balchin et al. (2016) have stated that output, employment and foreign direct investment (FDI) in the manufacturing sector have increased over the past decade in sub-Sahara Africa. The researchers have further revealed that new opportunities are emerging in manufacturing subsectors such textiles, agro-allied, automobiles and consumer goods. However, the same cannot be said of the manufacturing sector in Nigeria. Many challenges are bedevilling the manufacturing firms in Nigeria, resulting in slow pace of development in the country's pursuit of economic diversification. Most of these challenges arise because of the unfriendly nature of Nigeria's business environment (Ehie \& Muogboh, 2016).

In spite of enormous potentials in human and natural resources, various impediments, such as corruption, unstable power supply, high energy costs, inconsistent regulatory and legal environment, insecurity and ineffective judicial system, have continued to plague the development of manufacturing sector in Nigeria (US Department of State [USDS], 2015). Lack of infrastructural facilities, especially unstable power supply (electricity), immensely contribute to the high operating costs of manufacturing firms in the country. A study has revealed that listed manufacturing companies with the Manufacturers' Association of Nigeria (MAN) have dropped from 4850 in the 1980s to 2000 in 2010 (Raphael \& Gabriel, 2015). Raphael and Gabriel (2015) further argued that capacity utilisation of the sector dropped from $70.1 \%$ in 1980 to $52.8 \%$ in 2005 and $48.0 \%$ in 2009 , resulting in the liquidation of many of the manufacturing firms. Between 2000 and 2008 alone, an estimated 820 manufacturing firms liquidated or temporarily suspended operations (Mike, 2010). Hardly any nation could experience meaningful economic development without a strong and vibrant manufacturing sector. This is because the manufacturing sector is noted to contribute in no small measures to the economic growth and development of most countries of the world (Maiyaki, 2013; Sola, Obamuyi, Adekunjo, \& Ogunleye, 2013). The presence of thriving manufacturing sector ensures the growth of an economy through the production of quality goods for local consumption and export to earn foreign revenue (Okoiye, Onah, \& Atsaka, 2015).

The manufacturing sector in Nigeria has a chequered history. The sector has continued to evolve through different stages prior to the country attaining independence in 1960 to the present day (Maiyaki, 2013). Prior to independence, the manufacturing sector's focus was characterised by agricultural production for local consumption and export (Raphael \& Gabriel, 2015). During pre-independence period, raw materials were produced for export to foreign companies, whilst the finished products were imported for local consumption. Mike (2010) explained that post-independence Nigerians witnessed an emphasis on rapid industrialisation in the policy framework of the government. Import substitution strategy was introduced to encourage local production of imported goods. The import substitution strategy was consolidated in the Nigeria's second National Development Plan period of 1970-1974, during which the country experienced boom in oil and gas sector (Sola et al., 2013). The oil boom attracted many global investors, as there 
was an increase in FDI. The GDP from the sector increased from $3.2 \%$ in 1960 to $9.5 \%$ in 1975 (Mike, 2010). However, the collapse of global oil market experienced in the early eighties led to a downward trend in the foreign exchange earnings of Nigeria with adverse effect on the manufacturing sector (Mike, 2010; Sola et al., 2013). Negative trends in oil revenue and the currency exchange rate between 1982 and 1986 necessitated the rationing of foreign exchange amongst manufacturing firms (Ejohwomu, Onifade, \& Adeoye, 2016; Mike, 2010). Fluctuations in the global oil market often affected Nigeria's economy because of its over reliance on crude oil as a major source of foreign exchange earnings.

The policy thrust of Nigerian government in the 21st century is the pursuance of industrialisation through continuous development in science and technology, product development, improvement in quality and quantity of manufactured goods, production of products which could produce other products and building manufacturing sector that could withstand competitiveness (Ehie \& Muogboh, 2016). This policy thrust could be enhanced by building a sustainable manufacturing sector.

\section{Relationship between work-life balance strategies and organisational performance}

Globalisation has brought about demographic shifts in labour market. The changing demographics mean that employees are saddled with more responsibilities from the family domain, in addition to the concern to achieve success in the work domain (Ko \& Hur, 2014). More so, the level of competitiveness which has made it difficult for organisations to attract and retain the best talent in the labour market has propelled the attention given to WLBS (Caillier, 2016). Organisations are keeping pace with this trend to enhance performance and create greater competitive advantage. However, organisation's inability to effectively implement WLBS may result in employees living in perpetual anxiety (Zheng et al., 2016). Work-life balance strategies (sometimes referred to as work-life policies or family-friendly policies in literature) are aligned with organisational HR strategies to help employees manage work and non-work aspects of their lives. Felstead, Jewson, Phizacklea and Walters (2002) see WLBS as the factors, whether intentionally or otherwise, that enhance the flexibility and autonomy of an employee in negotiating attention and presence in employment. Organisations around the world have seen the need to adopt WLBS as part of HR strategies to help employees cope with stressors and attract the best talent in a competitive labour market (Abe et al., 2018; Hirschi et al., 2019).

It is generally assumed that employees derive benefits from organisational WLBS. However, it is not clear whether workers have equal access to it (Caillier, 2016). The effective implementation of WLBS implies equity. In essence, employees are able to achieve balance between work and life roles. Life responsibilities vary from one person to another and it is based on many factors, which include marital status, gender orientation, childcare, extended family demands, hobbies/interests and many other dynamics apart from work (Mazerolle, Eason, \& Trisdale, 2015). A study conducted by Perry-Smith and Blum (2000) has revealed that organisations that implement WLBS such as flexible work arrangement, on-site day care and dependent care experienced improved performance. Beauregard and Henry (2009) have attributed the business case of WLBS to include attraction and retention of skilled employees to enhance organisational outcomes.

However, empirical evidences have revealed that many employees are not accessing the WLBS provided by their organisations because of perceived negative consequences (Beauregard \& Henry, 2009; Daverth, Cassell, \& Hyde, 2016). Consistent with this argument, Russo (2015) points out that employees are reluctant to use flexible policies even when they are entitled to use it to show commitment to the organisation. For instance, an employee that makes use of organisational flexible work arrangements, such as telecommuting and part-time work, may not be considered for promotion. This is because telecommuting and parttime working are said to be incompatible with promotion in an organisation with a greater number of men at managerial positions (Russo, Shteigman, \& Carmeli, 2016). The inability to access and use organisational WLBS such as flexible work arrangement may result in low productivity, higher stress, work-family conflict and health disorders (Russo, 2015).

Human resource managers, whether at senior or supervisory level, have a major role to play in the effective implementation of WLBS as they have the capacity to encourage or discourage employees from accessing the WLB initiatives of an organisation (Wei et al., 2013). Deery and Jago (2015) suggest that a major determinant of effective implementation of WLBS is HR policy that affirms work-life balance culture. As such, it is the WLBS that an organisation has put in place that determines the extent of employees' satisfaction with work (SWW), commitment to work and turnover intention (Abe et al., 2018; Coetzee, Ferreira, \& Potgieter, 2017). Studies have revealed that a supportive HR policy enhances the effective implementation of WLBS (Caillier, 2016, Daverth et al., 2016). The major obstacle to the effective implementation of WLBS in the manufacturing sector of Lagos metropolis has been identified as the lack of direct involvement of senior management and improper communication with staff members (Ganiyu, Fields, \& Atiku, 2017).

The consciousness of the changing needs of employees and the provision of effective WLBS are plausible in employees' retention (De Cieri et al., 2005). Daverth et al. (2016) argue that organisational strategies aimed at helping employees cope with the competing demands of work and non-work aspects of employees' lives are reciprocated by employees through productivity and commitment to job. The assumption is that WLBS is a reciprocal gain system that 
benefits organisations and their employees (Caillier, 2016; Las Heras, Bosch, \& Raes, 2015). Whilst WLBS could be valuable in managing employees work-family stressors (WFS), organisations benefit from WLBS through reduction in the stress level of employees and turnover intentions, thereby enhancing organisational performance (Las Heras et al., 2015).

The reality amongst corporate bodies in the 21st century is the view that the alignment of WLBS to HR strategies can enhance employees' productivity with an impact on organisational outcomes (Russo et al., 2016). As such, resources are being invested in various contexts on WLBS with a view of adapting work to the changing employee work-life needs and as a response to government policies aimed at promoting gender integration in the labour force (Caillier, 2016). However, studies have revealed that organisational characteristics, such as size, gender composition and management structure, influence the types of WLBS that are put in place (Dancaster, 2014). Organisational efforts aimed at helping employees achieve balance may include the implementation of WLBS such as flexible work arrangement, child and elder care options, employees' health and wellness programmes, leave options and stress management (De Cieri et al., 2005; Subramaniam, Overton, \& Maniam, 2015). This study is guided by conceptual framework presented in Figure 1. The framework is tested using International Business Mahines (IBM) Analysis of Moment Structures (AMOS), version 25.

In Figure 1, work and family stressors are exogenous variables, WLBS and work-family satisfaction (WFSat) are mediating variables, whilst organisational performance is an exogenous variable. Based on the foregoing, the following hypotheses were formulated:

H1: Work-life balance strategies mediate the relationship between WFS and manufacturing firms' performance.

H2: Work-family satisfaction mediates the relationship between work family stressors and manufacturing firms' performance.

The formulated hypotheses were tested using Structural Equation Modelling (SEM) via IBM AMOS.

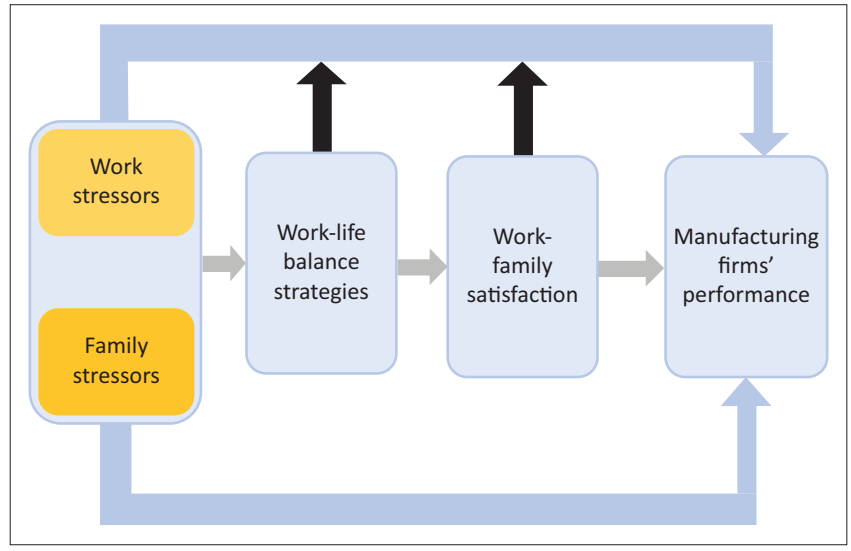

FIGURE 1: Conceptual framework to measure work-life balance strategies.

\section{Methods and sample}

This article employed a quantitative research design to test and validate a model to measure the effectiveness of WLBS. The target population comprised 508 employees of two selected manufacturing firms in Lagos metropolis. Five manufacturing firms quoted on the Nigerian Stock Exchange were approached for the purpose of data collection. Only two of the five firms approached indicated interest in allowing their employees to participate in the survey. The principle of convenience sampling technique was adopted to select the two manufacturing firms willing to participate in this survey. The rationale for adopting a convenience sampling technique in a study of this nature is that it allows data to be collected from members of a population who are conveniently accessible to provide it (Sekaran \& Bougie, 2016). Selfadministered questionnaires using a 5-point Likert type rating scale were used to collect data from employees of the two selected manufacturing firms in Lagos metropolis. A simple random sampling technique was adopted to administer 312 questionnaires to the study respondents. The survey was conducted amongst employees of all levels across departments within the firms surveyed; IBM SPSS, version 25, was used to conduct descriptive statistics of the demographic data. IBM AMOS, version 24, was employed to run Confirmatory Factor Analysis (CFA) and SEM. Structural equation modelling is a second-generation multivariate statistical technique employed to test conceptual framework and establish path analysis amongst the composite variables measured in this study. Convergent and discriminant validity was conducted to ensure the validity of composite variables. This was achieved by using the Average Variance Extracted and Fornell and Larcker (1981) criterion.

\section{Measures}

\section{Exogenous latent variable: Work-family stressors}

Work stressors were measured with 15-item scale adapted from 30-item scale developed by Rizzo, House and Lirtzman (1970). The items from Rizzo et al. (1970) were originally developed to measure role conflict and role ambiguity which are dimensions of work-stressors considered in this study. The scale by Rizzo et al. (1970) has been used extensively and validated by previous studies in the measure of work stressors, role ambiguity, role conflict and work-family conflict (Ganiyu et al., 2017; González-Romá \& Lloret, 1998). Cronbach's alpha for the 15-item scale adapted for measuring work stressors is 0.82 , which is above the acceptable threshold of 0.70 .

The scale for measuring family-stressors was adapted from Kopelman, Greenhaus and Connolly (1983). Kopelman et al. (1983) grouped the 24-item scale into three to measure work conflict, family conflict and inter-role conflict. The items measuring family conflict and inter-role conflict which are consistent with the dimensions of family stressors construct were reworded and included in the scale measuring family stressors in this study. The items were reworded for simplicity 
and clarity to ensure that this study's respondents have a clearer understanding of each item. For instance, items such as 'Because of my family situation, I have too little time to pursue my personal interests' was reworded to 'I do not have time for my friends and hobbies' and 'my work takes up time that I'd like to spend with my family' was reworded to 'I do not spend time with family'. The 15-item scale adapted has a very good reliability with Cronbach's alpha of 0.87 . The adapted scale was valuable in eliciting responses from the study respondents using a 5-point Likert type rating scale.

\section{Mediating variables: Work-life balance strategies and work-family satisfaction}

Work-life balance strategies were measured on 15-item scale adapted from De Cieri et al. (2005). This scale was used to elicit responses from the study respondents on the various WLBS such as flexible work arrangements, employees' health and wellness programmes, paid maternity/maternity leave and child care facility implemented by the manufacturing firms. The Cronbach's alpha test of reliability for the adapted scale was 0.88 .

A combination of the revised version of the Job Descriptive Index (JDI) and Minnesota Satisfaction Questionnaire (MSQ) were adapted to measure SWW. The JDI as developed by Smith, Kendall and Hulin (1969) measures various dimensions of work satisfaction; the authors defined satisfaction 'as the feelings a worker has about his job'. The JDI was validated and revised by Kinicki, Mckee-Ryan, Schriesheim and Carson (2002).The average internal consistency values for 'the revised JDI were $0.87,0.88,0.86,0.88$ and 0.89 for satisfaction with pay promotion, co-workers, work and supervision respectively' (Kinicki et al., 2002, p. 16).

Satisfaction with family life was adapted from the three-item scale developed by Edwards and Rothbard (1999). It included items such as; 'I am satisfied with the conditions of my familylife'. The scale is very reliable with a Cronbach's alpha coefficient of 0.97 . The scale was supported by three-item family satisfaction scale developed by Diener, Emmons, Larsen and Griffin (1985). The reliability tests for the scale were 0.85 and 0.87 respectively. Responses were provided on a 5-point Likert-type rating scale from strongly disagree (1) to strongly agree (5). The least score represents lack of family satisfaction, whilst the highest score in the rating scale represents high level of family satisfaction. Overall, the adapted scale for this study amounted to 10-item scales, each used to measure SWW and satisfaction with family. The Cronbach's alpha coefficient tests of reliability for the two scales were 0.90 and 0.92 respectively. The reliability test was consistent with the rule of thumb as alpha coefficients ranged from acceptable to excellent values at 0.90 and 0.92 (Pallant, 2011).

\section{Endogenous latent variable: Organisational performance}

Some six items were developed to measure organisational performance. The reliability of the items was ascertained to ensure that they measure what they were supposed to measure. The Cronbach's alpha for the organisational performance scale was above 0.80 , which is considered very good. This shows that the scale was very reliable in measuring the performance of the selected manufacturing firms.

\section{Ethical consideration}

Ethical clearance was obtained from the Humanities and Social Sciences Research Ethics Committee of the University of KwaZulu-Natal. As part of the ethical requirement, a written request was sent to the manufacturing firms where the survey for this study was conducted, with approval granted by the firms through the issuance of gatekeeper's letter. The anonymity of the respondents was ensured through the signing of the informed consent attached with the survey questionnaire.

\section{Analysis and results}

The analysis was conducted in three stages. In the first stage, Exploratory Factor Analysis (EFA) was conducted to establish the factor loadings of items for each construct. The result of EFA saw item three of the job performance scale cross-loading to the SWW scale and was subsequently renamed SWW3. Secondly, first and second-order CFA were conducted. The third stage presents SEM. The next section presents the outcome of the EFA analysed using SPSS version 25. The outcome of the descriptive and inferential statistics using SPSS version 25 and IBM AMOS version 25 are presented in this section. The factor structure of EFA on the mediating influences of WLBS and WFSat on the interplay between WFS and manufacturing firms' performance are presented in Table 1 .

\section{Exploratory factor analysis}

Exploratory factor analysis was adopted to determine the factor structure of items measuring the variables considered in this study. The principal component analysis helped to determine factors to be extracted. The sets of observed variables which are constantly moving together were identified through the factor extraction (Ul Hadia, Abdullah, \& Sentosa, 2016). The items identified through extraction in the EFA helped to determine the factors to be included in the CFA (Pallant, 2011; Ul Hadia et al., 2016). Items with good factor loadings were retained for CFA. According to Comrey and Lee (1992), an item with a good factor loading has a loading of higher or equal to 0.71 . The Kaiser-Meyer-Olkin (KMO) test was valuable to determine the appropriateness and adequacy of the study sample size. Kaiser (1974) suggests 0.50 as the threshold for $\mathrm{KMO}$, whilst the values between 0.50 and 0.70 are considered mediocre, values between 0.70 and 0.80 are considered good, values between 0.80 and 0.90 are considered great and 0.90 and above values are considered excellent (Pallant, 2011; Ul Hadia et al., 2016). Pallant (2011) recommends that the $\mathrm{KMO}$ value should be 0.60 or above. Consistent with Cattell's (1966) recommendation of retaining all factors above the elbow, this study retained factors with 
TABLE 1: Exploratory factor analysis of measuring instruments.

\begin{tabular}{|c|c|c|c|c|c|c|c|}
\hline \multirow[t]{2}{*}{ Items } & \multicolumn{6}{|c|}{ Item factor loadings } & \multirow{2}{*}{$\begin{array}{l}\text { Corrected item - total } \\
\text { correlation }\end{array}$} \\
\hline & 1 & 2 & 3 & 4 & 5 & 6 & \\
\hline WS_15 & 0.828 & - & - & - & - & - & 0.647 \\
\hline WS_14 & 0.826 & - & - & - & - & - & 0.704 \\
\hline WS_13 & 0.716 & - & - & - & - & - & 0.601 \\
\hline WS_8 & 0.502 & - & - & - & - & - & 0.459 \\
\hline FS_6 & - & 0.841 & - & - & - & - & 0.655 \\
\hline FS_7 & - & 0.826 & - & - & - & - & 0.608 \\
\hline FS_11 & - & 0.714 & - & - & - & - & 0.632 \\
\hline FS_12 & - & 0.696 & - & - & - & - & 0.562 \\
\hline FS_2 & - & 0.695 & - & - & - & - & 0.591 \\
\hline WLBS_12 & - & - & 0.871 & - & - & - & 0.637 \\
\hline WLBS_14 & - & - & 0.832 & - & - & - & 0.682 \\
\hline WLBS_13 & - & - & 0.819 & - & - & - & 0.608 \\
\hline WLBS_11 & - & - & 0.733 & - & - & - & 0.720 \\
\hline WLBS_15 & - & - & 0.706 & - & - & - & 0.637 \\
\hline SWF_4 & - & - & - & 0.897 & - & - & 0.761 \\
\hline SWF_7 & - & - & - & 0.783 & - & - & 0.691 \\
\hline SWF_8 & - & - & - & 0.770 & - & - & 0.684 \\
\hline SWF_6 & - & - & - & 0.738 & - & - & 0.685 \\
\hline SWF_5 & - & - & - & 0.731 & - & - & 0.575 \\
\hline SWF_2 & - & - & - & 0.729 & - & - & 0.653 \\
\hline SWF_9 & - & - & - & 0.718 & - & - & 0.677 \\
\hline SWF_3 & - & - & - & 0.694 & - & - & 0.575 \\
\hline SWW_5 & - & - & - & - & 0.860 & - & 0.766 \\
\hline SWW_9 & - & - & - & - & 0.808 & - & 0.768 \\
\hline SWW_7 & - & - & - & - & 0.748 & - & 0.681 \\
\hline SWW_4 & - & - & - & - & 0.713 & - & 0.647 \\
\hline SWW_3 & - & - & - & - & 0.710 & - & 0.561 \\
\hline SWW_8 & - & - & - & - & 0.572 & - & 0.619 \\
\hline SWW_2 & - & - & - & - & 0.454 & - & 0.625 \\
\hline OP_1 & - & - & - & - & - & 0.786 & 0.690 \\
\hline OP_2 & - & - & - & - & - & 0.808 & 0.733 \\
\hline OP_3 & - & - & - & - & - & 0.692 & 0.649 \\
\hline OP_4 & - & - & - & - & - & 0.854 & 0.785 \\
\hline OP_6 & - & - & - & - & - & 0.773 & 0.663 \\
\hline Cronbach's $\alpha$ & 0.791 & 0.818 & 0.844 & 0.889 & 0.881 & 0.871 & - \\
\hline Eigenvalue & 1.683 & 2.032 & 3.252 & 13.514 & 3.854 & 2.223 & - \\
\hline Variance $(\%)$ & 3.164 & 3.820 & 6.113 & 25.406 & 7.246 & 4.179 & - \\
\hline
\end{tabular}

WS, work stressors; FS, family stressors; WLBS, work-life balance strategies; SWF, satisfaction with family; SWW, satisfaction with work; OP, organisational performance.

$\mathrm{KMO}=0.87 ; x^{2}=7935.259 ; d f=1035 ; p<0.001$.

Eigenvalue greater than 1 (DeVellis, 2016). Other items with poor loadings were deleted. The corrected item-total correlation was valuable in ensuring the purification of items to prevent less important items from confounding the interpretation of EFA. The Cronbach's alpha coefficient was employed to measure the internal consistency of extracted factors. Table 1 presents the factor structure of items retained for CFA.

The illustration in Table 1 represents items retained for the six factors. The overall result indicates good reliability of all the factors extracted in this study, given that the Cronbach's alpha coefficient for all the factors is more than 0.70 . The Eigenvalue for the first factor which measures work stressors is 1.683 and explained $3.2 \%$ of the data. The second factor which measures family stressors has an Eigenvalue of 2.032 with $3.8 \%$ of variance explained. Factor three which measures WLBS showcases Eigenvalue of 3.252 and explained $6.1 \%$ variance of the original data. The fourth factor measuring satisfaction with family produced an Eigenvalue of 13.514 and explained $25.4 \%$ of item variance. Factor five which measures SWW has an Eigen value of 3.854 and explained $7.3 \%$ of item variance. Factor six measuring organisational performance (manufacturing firms' performance) has an Eigen value of 2.223 and explained $4.2 \%$ of the total variance. The factor loadings revealed that virtually all items retained in each construct have loadings more than 0.50, which are considered excellent, very good or good. Only one item (SWW_2) has a loading less than 0.50 . The KMO test of 0.87 is an indication that the study sample size of 312 is adequate. The Bartlett test of sphericity is significant at $p<0.001$, which justified why the EFA was performed.

\section{Measurement model on the mediating influences of work-life balance strategies and work-family satisfaction}

IBM AMOS graphic was used to conduct CFA. As indicated by Hair Jr, Sarstedt, Hopkins and Kuppelwieser (2014), CFA is conducted to test the extent to which a researcher's a priori and theoretical pattern of factor loadings on pre-specified constructs represent the actual data. The purpose of CFA is therefore to confirm the structure of constructs. The secondorder CFA was considered in measuring the mediating influences of WLBS and WFSat on the interplay between WFS and organisational performance.

A second-order CFA is a statistical method aimed at confirming whether a construct loads onto certain number of underling sub-constructs (Thompson, 2007). According to Herman (2016), the decision on whether to conduct a secondorder CFA is determined by the needs of a study. The secondorder CFA was conducted in this article to establish the effects a main construct had on sub-constructs (Herman, 2016). Two latent constructs, which include WFS and WFSat (a mediator), are specified as of second order. These two constructs are linked with their sub-constructs with a onesided arrow to depict their causal effects. Work-family stressors are linked to family stressors and work stressors, whilst WFSat is linked with satisfaction with work and satisfaction with family. The second-order CFA was valuable in hypothesising the model into four latent constructs of WFS (endogenous variable), WLBS (first mediator), WFSat (second mediator) and organisational performance (exogenous variable). Figure 2 presents the statistical analysis of the second-order CFA.

Figure 2 illustrates the results of the model fit indices for the second-order CFA. The second-order CFA was carried out by combining first-order constructs. Family stressors and work stressors were combined to WFS, whilst satisfaction with family and satisfaction with work were combined with WFSat. The model fit indices indicated CMIN/ $d f$ value of 2.036 and RMSEA value of 0.058 , which were within the 


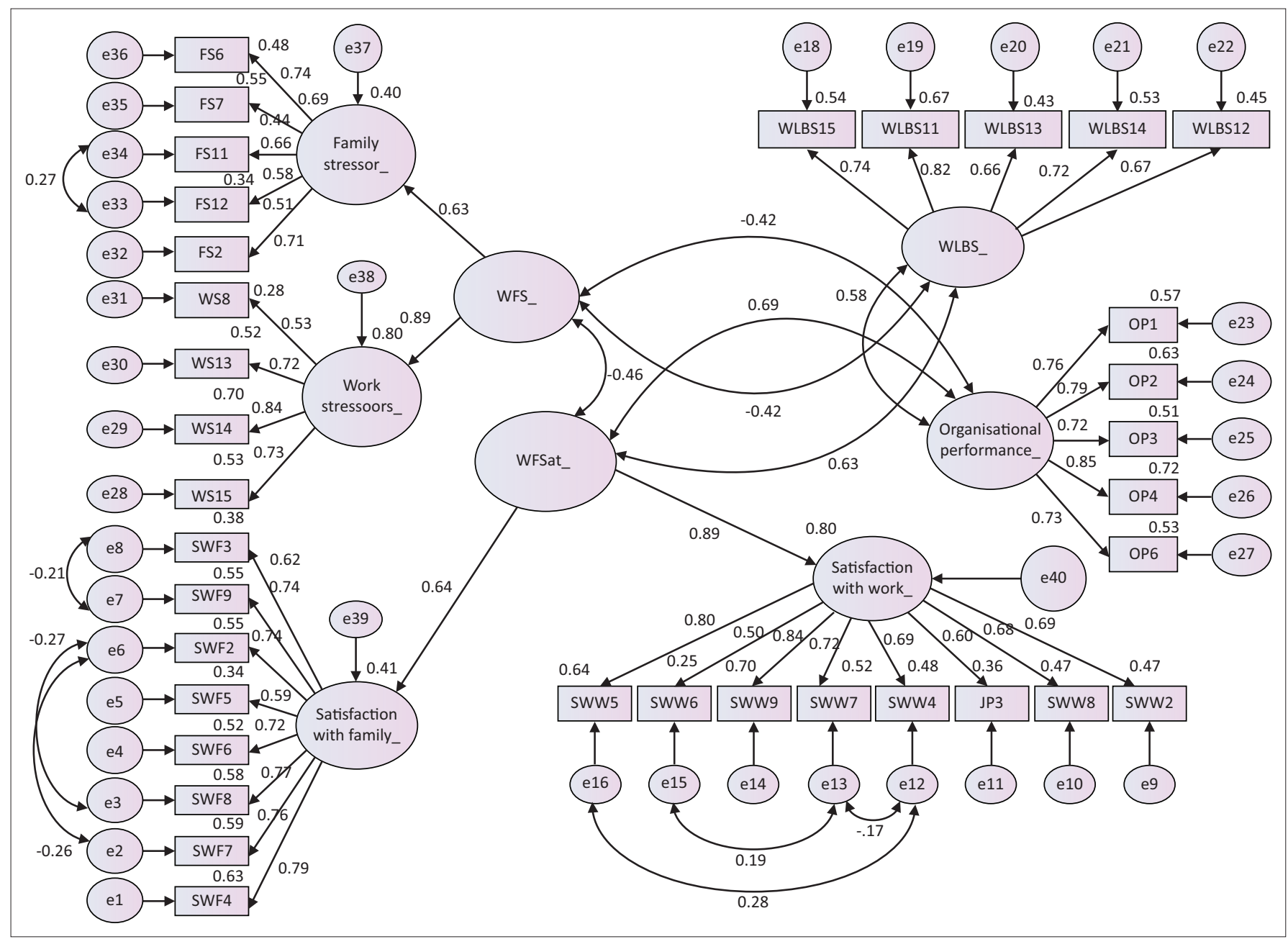

WS, work stressors; FS, family stressors; WLBS, work-life balance strategies; SWF, satisfaction with family; SWW, satisfaction with work; OP, organisational performance. $\mathrm{CMIN}=1095.175 ; d f=538 ; p<0.000 ; \mathrm{CMIN} / d f=2.036 ; \mathrm{GFI}=0.839 ; \mathrm{AGFI}=0.811 ; \mathrm{NFI}=0.820 ; \mathrm{IFI}=0.899 ; \mathrm{TLI}=0.887 ; \mathrm{CFI}=0.898 ; \mathrm{RMSEA}=0.058$. FIGURE 2: Hypothesised four-factor model (second-order ss).

acceptable threshold. In addition, the composite reliability and validity of the second-order CFA was conducted. Table 2 shows the results of the composite reliability and validity of constructs in the second-order CFA.

As shown in Table 2, the of reliability of the constructs in the measurement model was established using composite reliability. Composite reliability is considered a more appropriate measure of reliability of the instruments which measures latent variables (Hair et al., 2014). In addition, composite reliability, otherwise referred to as DillonGoldstein's rho, is a more credible measure of reliability than Cronbach's alpha in SEM because it is based on loadings and not on observed correlations between variables (Demo, Neiva, Nunes, \& Rozzett, 2012). It is observed in Table 2 that the composite reliability of each construct is above the threshold of 0.70 . This shows that all constructs in the model are consistent.

The validity of the research instrument was achieved using AVE. The AVE was applied to ensure the convergent validity of constructs. The values of AVE revealed that the loading for each construct is more than the acceptable level of 0.50 . This implies that each of the constructs with explained over $50 \%$ of
TABLE 2: Reliability analysis, convergent and discriminant validity assessment.

\begin{tabular}{lccccccc}
\hline Constructs & CR & AVE & MSV & 1 & 2 & $\mathbf{3}$ & 4 \\
\hline 1. Organisational performance & 0.879 & 0.593 & 0.472 & 0.770 & - & - & - \\
$\begin{array}{l}\text { 2. Work-family stressors (WFS) } \\
0.745\end{array}$ & 0.600 & 0.209 & -0.418 & 0.775 & - & - \\
$\begin{array}{l}\text { 3. Work-family satisfaction } \\
\text { (WFSat) }\end{array}$ & 0.746 & 0.602 & 0.472 & 0.687 & -0.457 & 0.776 & - \\
$\begin{array}{l}\text { 4. Work-life balance strategy } \\
\text { (WLBS) }\end{array}$ & 0.845 & 0.524 & 0.397 & 0.575 & -0.424 & 0.630 & 0.724 \\
\hline
\end{tabular}

Note: All correlations are significant at $p<0.001$. Diagonals are the square roots of AVE.

$C R$, AVE and MSV.

its item variance. The Fornell and Larcker (1981) criterion was applied to ensure discriminant validity of all constructs. This was achieved by comparing the cross-loading of all constructs with the square roots of AVE as depicted by values of the diagonal in Table 2. In addition, discriminant validity is denoted as AVE values greater than MSV values (AVE > MSV). The MSV values (AVE > MSV) show that all constructs in this article did not violate discriminant validity (Herman, 2016).

\section{Structural model}

The structural model in Figure 3 examines the mediating influences of WLBS and WFSat on the interplay between WFS and organisational performance. Bootstrapping method 


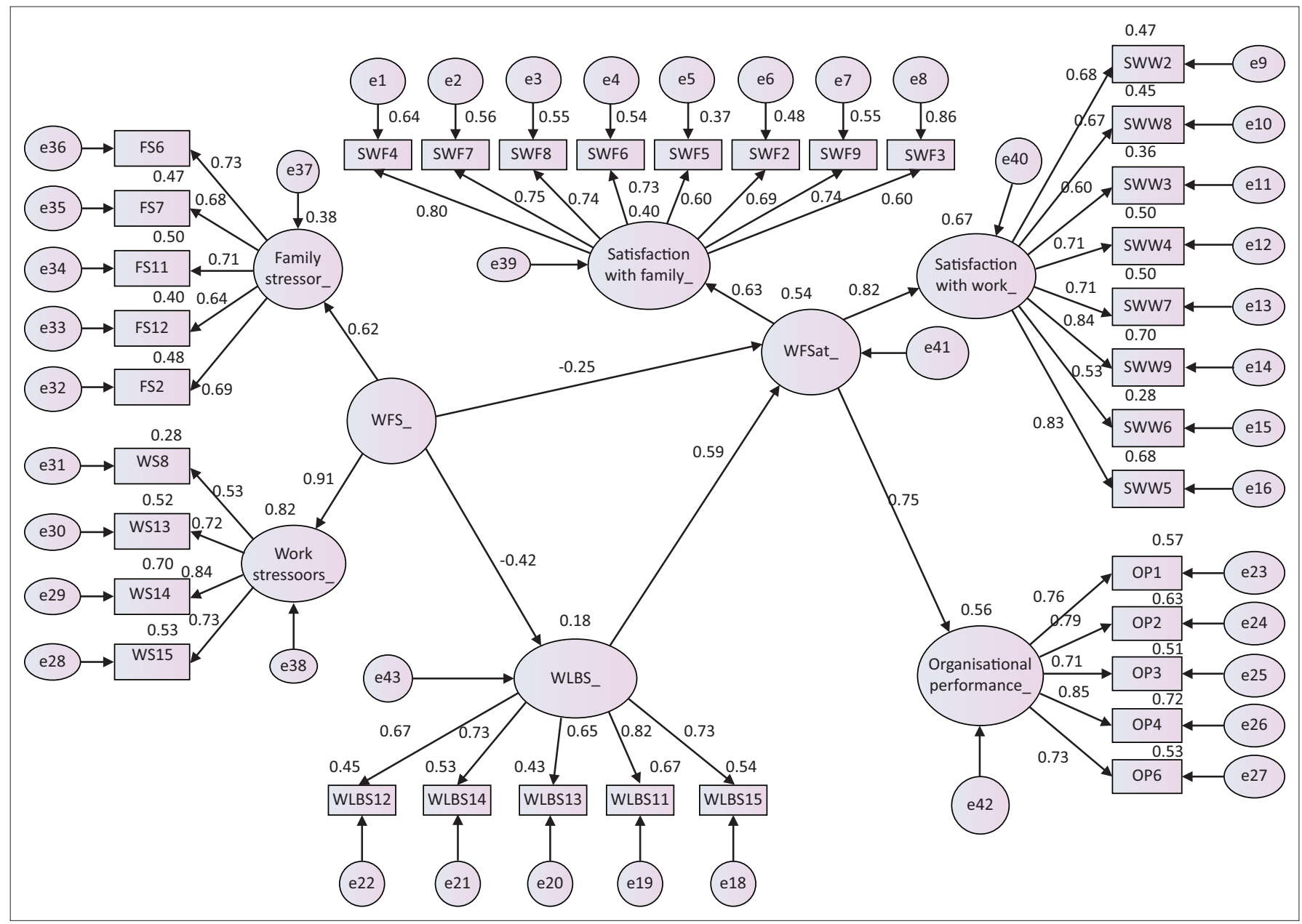

WS, work stressors; FS, family stressors; WLBS, work-life balance strategies; SWF, satisfaction with family; SWW, satisfaction with work; OP, organisational performance. $\mathrm{CMIN}=1274.688 ; d f=552 ; p<0.000 ; \mathrm{CMIN} / d f=2.309 ; \mathrm{GFI}=0.813 ; \mathrm{AGFI}=0.787 ; \mathrm{NFI}=0.790 ; \mathrm{IFI}=0.869 ; \mathrm{TLI}=0.858 ; \mathrm{CFI}=0.868 ; \mathrm{RMSEA}=0.065$.

FIGURE 3: Mediating influences of work-life balance strategies and work-family satisfaction.

was employed for mediation analysis. The fit indices extracted from AMOS output indicate good fit of structural model.

Figure 3 indicates a good fit of structural model. The standardised regression weight from WFS to WLBS is $\beta=-0.422$ and $p<0.000$. This result indicates a significant negative relationship between WFS and WLBS in the selected manufacturing firms of Lagos metropolis. The inverse relationship implies that an improvement in the effectiveness of WLBS would bring about reduction in the WFS of employees of the selected manufacturing firms in Lagos metropolis. Likewise, the direct path from WFS to WFSat depicts a significant negative relationship at $\beta=$ -0.25 and $p=0.018$. This result implies that as employees of the selected manufacturing firms continue to experience satisfaction with work-family lives, the stressors emanating from work and family domains of the employees continue to decline. However, the structural model illustrated a direct significant positive effect between WLBS and WFSat at $\beta=0.590$ and $p=0.001$. By implication, an increase in the availability and effectiveness of WLBS put in place brings about increase in the level of WFSat of employees of the selected manufacturing firms in Lagos metropolis.
The standard regression weight also revealed a direct significant positive effect between WFSat and the selected manufacturing firms' performance $(\beta=0.752, p=0.001)$. Statistically, the result implies that employees' satisfaction with work-family life exert a direct positive effect on the performance of selected manufacturing firms. Based on the outcome of the structural model, WLBS exert an indirect positive effect on the selected manufacturing firms' performance via WFSat. The outcome of mediation analysis was subjected to Sobel test, Arorian test and Goodman test calculators for the significance of mediation. The results confirmed that WLBS mediates the relationship between WFS and manufacturing firms' performance at $p<0.001$. The result confirmed that WLBS and WFSat mediate the interplay between WFS and organisational performance. Based on this outcome, the formulated hypotheses H1 and $\mathrm{H} 2$ are supported.

\section{Discussion}

The path from WFS to WFSat was statistically significant. The direct path from WFS to organisational performance was not significant. This justified whilst no link was displayed between the two constructs (Figure 3). Therefore, WFS exerts a significant indirect effect on organisational performance via 
WFSat. This outcome implies that WFSat fully mediates the relationship between WFS and performance of selected manufacturing firms in Lagos metropolis. Also, the direct path from WFS and WLBS is significant. In other words, the WLBS put in place by the selected manufacturing firms was effective in cushioning the effects of stressors emanating from work and family domains. This is evident from the statistically significant relationship between WFS and WLBS. However, the direct path between WLBS and the selected manufacturing firms' performance is not significant, rather WLBS exerts indirect influence on the manufacturing firms' performance via WFSat.

Given the outcome of statistical analysis, the effectiveness of the adopted WLBS in addressing work and family stressors could result in employees having satisfaction with work and family lives, which invariably enhances the performance of the selected manufacturing firms (organisational performance) in Lagos metropolis. This finding aligns with the empirical study conducted by Organ, Podsakoff and MacKenzie (2006), in which it was found that WLBS tends to enhance employees' organisation citizenship behaviour with positive effect on the performance of the organisation.

The structural model given in Figure 3 revealed that the direct path from WLBS to WFSatis is statistically significant. This explains why Carlson, Grzywacz and Kacmar (2010) affirmed that the alignment of WLBS, such as flexible work arrangement, employees' health and wellness, and training and development programmes, could enhance employees' commitment and generally enhance satisfaction with work and family. Perry-Smith and Blum (2000) found that organisations that implement WLBS, such as flexible work arrangement, on-site day care and dependent care, experienced improved performance. A recent study performed by Coetzee et al. (2017) showcase that organisational retention strategy that includes WLBS, such as flexible work arrangement, enhances

\section{Conclusion}

This article contributes to the existing literature in the worklife debate. Work-life balance stems from the assumption that individuals are usually confronted by work and family stressors. Finding a balance between employees work and family lives is considered a strategic HR function. This research provided perspectives on the significance and the benefits of effectively implementing WLBS by the manufacturing firms in Lagos metropolis. This was realised by empirically establishing the interplay between WFS and the selected manufacturing firms' performance. The proposed framework, which is generalised to the manufacturing firms in Lagos metropolis, could be considered in the design of WLBS by various sectors of Nigerian economy.

In spite of the contribution of this study, there are some limitations from which further study could be conducted. This is a cross-sectional study which limits data collected to two manufacturing firms in Lagos metropolis, Nigeria.
The future research could expand the scope of study to other manufacturing firms in the six geopolitical zones of Nigeria to be able to make generalisation of the research findings to Nigeria.

\section{Acknowledgements Competing interests}

The authors have declared that no competing interests exist.

\section{Authors' contributions}

All authors contributed equally to this work.

\section{Funding information}

This research received no specific grant from any funding agency in the public, commercial or not-for-profit sectors.

\section{Data availability statement}

Data sharing is not applicable to this article as no new data were created or analysed in this study.

\section{Disclaimer}

The views and opinions expressed in this article are those of the authors and do not necessarily reflect the official policy or position of any affiliated agency of the authors.

\section{References}

Abe, E.N., Abe, I.I., Fields, Z., \& Idris, G.O. (2018). Work-family stressors and workfamily satisfaction: Effect of sense of coherence at a metropolitan municipality. Work, 10(2), 74-88. https://doi.org/10.22610/jebs.v10i2(J).2218

Agba, A.M., Wilson, U.W., \& Innah, D.E. (2015). Correlates between family and employees' work-life in Nigeria: The need for proper integration. International Journal of Capacity Building in Education and Management, 2(3), 25-42.

Akanji, B., Mordi, C., \& Ojo, S. (2015). Reviewing gaps in work-life research and prospecting conceptual advancement. Petroleum - Gas University of Ploiesti Bulletin, Technical Series, 67(3), 21-30. Retrieved from https://search.ebscohost. com/login. aspx?direct=true \&db=a9h\&AN=110496861\&site=ehost-live

Balchin, N., Gelb, S., Kennan, J., Martin, H., Te Velde, D.W., \& Williams, C. (2016) Developing export-based manufacturing in sub-Saharan Africa. London: Department for International Development (DFID) and Overseas Development Institute (ODI).

Beauregard, T.A., \& Henry, L.C. (2009). Making the link between work-life balance practices and organizational performance. Human Resource Management Review, 19(1), 9-22. https://doi.org/10.1016/j.hrmr.2008.09.001

Brochard, D., \& Letablier, M.T. (2017). Trade union involvement in work-family life balance: Lessons from France. Work, Employment and Society, 31(4), 657-674. https://doi.org/10.1177/0950017016680316

Caillier, J.G. (2016). Does satisfaction with family-friendly programs reduce turnover ? A panel study conducted in US Federal agencies. Public Personnel Management, 45(3), 284-307. https://doi.org/10.1177/0091026016652424

Carlson, D.S., Grzywacz, J.G., \& Kacmar, K.M. (2010). The relationship of schedule flexibility and outcomes via the work-family interface. Journal of Managerial Psychology, 25(3), 330-355. https://doi.org/10.1108/02683941011035278

Cattell, R.B. (1966). The screen test for the number of factors. Multivariate Behavioral Research, 1(2), 245-276. https://doi.org/10.1207/s15327906mbr0102_10

Chete, L.N., Adeoti, J.O., Adeyinka, F.M., \& Ogundele, F.O. (2016). Industrial policy in Nigeria: Opportunities and challenges in a resource-rich country. In C. Newman, J. Page, J. Rand, A. Shimeless, M. Söderbom, \& T. Finn (Eds.), Manufacturing transformation: Comparative studies of industrial development in Africa and emerging Asia (pp. 1-29). New York: Oxford University Press.

Coetzee, M., Ferreira, N., \& Potgieter, I. (2017). Perceptions of sacrifice, workplace friendship and career concerns as explanatory mechanisms of employees organisational commitment. SA Journal of Human Resource Management, 17(1), 1-9. https://doi.org/10.4102/sajhrm.v17i0.1033

Comrey, A.L., \& Lee, H.B. (1992). A first course in factor analysis (2nd edn.). NJ: Hillsdale. 
Dancaster, L. (2014). Work-life balance and the legal right to request flexible working arrangements. South African Journal of Economic and Management Sciences, arrangements. South African Journal of Economic and
9(2), 175-186. https://doi.org/10.4102/sajems.v9i2.1144

Daverth, G., Cassell, C., \& Hyde, P. (2016). The subjectivity of fairness: Managerial discretion and work-life balance. Gender, Work \& Organization, 23(2), 89-107. https://doi.org/10.1111/gwao.12113

De Cieri, H., Holmes, B., Abbott, J., \& Pettit, T. (2005). Achievements and challenges for work/life balance strategies in Australian organizations. International Journal of Human Resource Management, 16(1), 90-103. https://doi.org/10.1080/ 0958519042000295966

Deery, M., \& Jago, L. (2015). Revisiting talent management, work-life balance and retention strategies. International Journal of Contemporary Hospitality Management, 27(3), 453-472. https://doi.org/10.1108/IJCHM-12-2013-0538

Demo, G., Neiva, E.R., Nunes, I., \& Rozzett, K. (2012). Human resources management policies and practices scale (HRMPPS): Exploratory and confirmatory facto analysis. BAR-Brazilian Administration Review, 9(4), 395-420. https://doi. org/10.1590/S1807-76922012005000006

DeVellis, R.F. (2016). Scale development: Theory and applications (Vol. 26). Thousand Oaks, CA: Sage.

Diener, E.D., Emmons, R.A., Larsen, R.J., \& Griffin, S. (1985). The satisfaction with life scale. Journal of Personality Assessment, 49(1), 71-75. https://doi.org/10.1207/ s15327752jpa4901_13

Edwards, J.R., \& Rothbard, N.P. (1999). Work and family stress and well-being: An examination of person-environment fit in the work and family domains. Organizational Behavior and Human Decision Processes, 77(2), 85-129. https:// Organizational Behavior and Hum
doi.org/10.1006/obhd.1998.2813

Ehie, I., \& Muogboh, O. (2016). Analysis of manufacturing strategy in developing countries: A sample survey of Nigerian manufacturers. Journal of Manufacturing Technology Management, 27(2), 234-260. https://doi.org/10.1108/JMTM-072014-0094

Ejohwomu, O.A., Onifade, M.K., \& Adeoye, A.B. (2016). Developmental programmes and policies: A logic model approach. Journal of Construction Project Management and Innovation, 6(2), 1429-1446.

Felstead, A., Jewson, N., Phizacklea, A., \& Walters, S. (2002). Opportunities to work a home in the context of work-life balance. Human Resource Management Journal, 12(1), 54-76. https://doi.org/10.1111/j.1748-8583.2002.tb00057.x

Fleetwood, S. (2007). Why work-life balance now? International Journal of Human Resource Management, 18(3), 387-400. https://doi.org/10.1080/ 09585190601167441

Fornell, C., \& Larcker, D.F. (1981). Evaluating structural equation models with unobservable variables and measurement error. Journal of Marketing Research, 18(1), 39. https://doi.org/10.2307/3151312

Ganiyu, I.O., Fields, Z., \& Atiku, S.O. (2017). Work-family stressors and manufacturing firms performance: Influence of work-life balance. Journal of Accounting and Management, 7(3), 60-71.

González-Romá, V., \& Lloret, S. (1998). Construct validity of Rizzo et al.'s (1970) role conflict and ambiguity scales: A multi-sample study. Applied Psychology, 47(4), 535-545. https://doi.org/10.1111/j.1464-0597.1998.tb00042.x

Guest, D.E. (2017). Human resource management and employee well-being: Towards a new analytic framework. Human Resource Management Journal, 27(1), 22-38. https://doi.org/10.1111/1748-8583.12139

Hair Jr, J.F., Sarstedt, M., Hopkins, L., \& Kuppelwieser, V.G. (2014). Partial least square structural equation modeling (PLS-SEM): An emerging tool in business research European Business Review, 26(2), 106-121. https://doi.org/10.1108/EBR-102013-0128

Herman, D.R. (2016). Research article CFA first-order and CFA second-orde (measurement model) of the special education teachers' readiness on the implementation of sexuality and health education for students with learning disabilities in special education (integration Pr). International Journal of Current Research, 8(10), 40165-40172.

Hirschi, A., Shockley, K.M., \& Zacher, H. (2019). Achieving work-family balance: An action regulation model. Academy of Management Review, 44(1), 150-171. https://doi.org/10.5465/amr.2016.0409

Kaiser, H.F. (1974). An index of factorial simplicity. Psychometrika, 39(1), 31-36. https://doi.org/10.1007/BF02291575

Kinicki, A.J., Mckee-Ryan, F.M., Schriesheim, C.A., \& Carson, K.P. (2002). Assessing the construct validity of the job descriptive index: A review and meta-analysis. The Journal of Applied Psychology, 87(1), 14-32. https://doi.org/10.1037/0021The Journal of

Ko, J., \& Hur, S. (2014). The impacts of employee benefits, procedural justice, and managerial trustworthiness on work attitudes: Integrated understanding based on social exchange theory. Public Administration Review, 74(2), 176-187. https:// on social exchange theory. Public

Kopelman, R.E., Greenhaus, J.H., \& Connolly, T.F. (1983). A model of work, family, and inter-role conflict: A construct validation study. Organizational Behavio and Human Performance, 32(2), 198-215. https://doi.org/10.1016/00305073(83)90147-2

Las Heras, M., Bosch, M.J., \& Raes, A.M. (2015). Sequential mediation among familyfriendly culture and outcomes. Journal of Business Research, 68(11), 2366-2373. https://doi.org/10.1016/j.jbusres.2015.03.042

Maiyaki, A.A. (2013). The challenges of textile and manufacturing industries in Kano Metropolis. Research Journal of the Institute of Business Administration KarachiPakistan, 8(2), 116-123.
Mazerolle, S.M., Eason, C.M., \& Trisdale, W.A. (2015). Work-life balance perspectives of male NCAA division I athletic trainers: Strategies and antecedents. Athletic Training and Sports Health Care, 7(2), 50-62. https://doi.org/10.3928/1942586420150216-01

McCarthy, A., Darcy, C., \& Grady, G. (2010). Work-life balance policy and practice: Understanding line manager attitudes and behaviors. Human Resource Management Review, 20(2), 158-167. https://doi.org/10.1016/j. hrmr.2009.12.001

Mike, J.A. (2010). Banking sector reforms and the manufacturing sector: The manufacturers' association of Nigeria perspective. Economic and Financial Review, 46(4), 57-65.

Mokyr, J. (2018). The British industrial revolution: an economic perspective. Oxfordshire: Routledge.

Newman, C., Page, J., Rand, J., Shimeles, A., Söderbom, M., \& Tarp, F. (2016). Made in Africa: Learning to compete in industry. Washington, DC: Brookings Institution Press.

Odubajo, T., \& Akinboye, S. (2017). Nigeria and South Africa: Collaboration or competition? South African Journal of International Affairs, 24(1), 61-77. https:// doi.org/10.1080/10220461.2017.1314224

Ogunnubi, O. (2017). Effective hegemonic influence in Africa: An analysis of Nigeria's 'hegemonic' position. Journal of Asian and African Studies, 52(7), 932-946. https://doi.org/10.1177/0021909616632277

Okoiye, O., Onah, T., \& Atsaka, J. (2015). Self-efficacy and emotional intelligence as predictors of employees job performance in manufacturing companies in Lagos state, Nigeria. Journal of Research in Education and Society, 6(1), 12-19.

Olugbenga, A.A., \& Grace, O.O. (2016). Impact of foreign direct investment on Nigerian capital market development. International Journal of Academic Research in Accounting, Finance and Management Sciences, 5(1), 103-108. https://doi. org/10.6007/ijarafms/v5-i1/1503

Organ, D.W., Podsakoff, P.M., \& MacKenzie, S.B. (2006). Organizational citizenship behaviour: Its nature, antecedents, and consequences. Thousand Oaks, CA: Sage.

Pallant, J. (2011). SPSS survival manual: A step by step guide to data analysis using SPSS (4th edn.). Perth: Allen \& Unwin.

Perry-Smith, J.E., \& Blum, T.C. (2000). Work-family human resource bundles and perceived organizational performance. Academy of Management Journal, 43(6), 1107-1117. https://doi.org/10.2307/1556339

Raphael, A.I., \& Gabriel, A.A. (2015). Effect of financial sector development on manufacturing output growth in Nigeria (1986-2012): A vector auto regression approach. Journal of Applied Economics \& Business Research, 5(1), 38-55.

Rizzo, J.R., House, R.J., \& Lirtzman, S. (1970). Role conflict and ambiguity in complex organizations. Administrative Science Quarterly, 15(2), 150-163. https://doi. org/10.2307/2391486

Rodó-de-Zárate, M., Garcia-Ramon, M.D., Villarino, M., Porto, A.M., Baylina, M., \& Salamaña, I. (2016). Work-life balance of professional women in rura Spain. Gender, Place \& Culture, 24(1), 72-84. https://doi.org/10.1080/096636 $9 x .2016 .1249345$

Russo, M. (2015). Work-home enrichment and health: An analysis of the mediating role of persistence in goal striving and vulnerability to stress. The International Journal of Human Resource Management, 26(19), 2486-2502. https://doi.org/10 1080/09585192.2014.1003085

Russo, M., Shteigman, A., \& Carmeli, A. (2016). Workplace and family support and work-life balance: Implications for individual psychological availability and energy at work. The Journal of Positive Psychology, 11(2), 173-188. https://doi.org/10.1 080/17439760.2015.1025424

Sekaran, U., \& Bougie, R. (2016). Research methods for business: A skill building approach (7th edn.). West Sussex: John Wiley.

Smith, P.C., Kendall, L.M., \& Hulin, C.L. (1969). The measurement of satisfaction in work and retirement: A strategy for the study of attitudes. Chicago, IL: Rand McNally.

Sola, O., Obamuyi, T.M., Adekunjo, F.O., \& Ogunleye, E. (2013). Manufacturing performance in Nigeria: Implication for sustainable development. Economic and Financial Review, 3(9), 1195-1213.

Subramaniam, A.G., Overton, B.J., \& Maniam, C.B. (2015). Flexible working arrangements, work-life balance and women in Malaysia. International Journal arrangements, work-life balance and women in Malaysia. International Journal
of Social Science and Humanity, 5(1), 34-38. https://doi.org/10.7763/IJSSH.2015. V5.417

Thompson, B. (2007). Exploratory and confirmatory factor analysis: Understanding concepts and applications. Applied Psychological Measurement, 31(3), 245-248. https://doi.org/10.1177/0146621606290168

UI Hadia, N., Abdullah, N., \& Sentosa, I. (2016). An easy approach to exploratory factor analysis: Marketing perspective. Journal of Educational and Social Research, 6(1), 215-223. https://doi.org/10.5901/jesr.2016.v6n1p215

US Department of State (USDS). (2015). Nigeria investment climate statement. Retrieved from https://www.state.gov/documents/organization/241898

Wei, C., Yili, L., \& Tian, Y. (2013). How can HRM help organizations build the supportive 'work-life/family 'balance culture? International Journal of Business and Social Science, 4(9), 104-110.

Zheng, C., Kashi, K., Fan, D., Molineux, J., Ee, M.S., Zheng, C., ... Ee, M.S. (2016) Impact of individual coping strategies and organisational work-life balance programmes on Australian employee well-being. The International Journal of Human Resource Management, 27(5), 501-526. https://doi.org/10.1080/09585 192.2015.1020447 